\title{
Employer Brand Equity and Its Impact on the Application Intent of the Prospective Employees
}

\author{
Dipali Shrikant Dalvi, Shreemati Nathibai Damodar Thackersey Women's University, India
}

\begin{abstract}
Skilled human capital marks organisational success. Attracting, recruiting, and retaining these employees is vital. Companies are applying branding principles to recruitment function. This is termed as employer branding (EB). Identifying a right fit to suit organizational needs is essential. Organizational communication plays a critical role to relate to job seekers of generation-i; they rely on information imparted via various media and decode their perception. In this study, it is evident that for job seekers, corporate websites are important sources of information while deciding their employer. The reviews on job hunting sites aid perception. Use of AI to relate to prospective employees adds competitive edge. This study was conducted to ascertain dimensions of EB and study the application intent of potential employees. It included students from engineering and management and the employees from the job market. The findings allowed comparison of application intent of three groups. Qualification and experience moderates' application intent of prospective employees was evident.
\end{abstract}

\section{KEYWORDS}

Employer Brand Equity, Perception, Recruitment, Right Fit

\section{INTRODUCTION}

In the technological era, infinite transformations are transpiring. Instantaneously organizations are facing intense competition, and customers have advanced to considerably "informed consumers" with the required data and information available at the touch of a button at their fingertips via their mobiles. These transitions influence and impact the approach of individual thinking and also the perception and, subsequently, the method we contemplate to correlate with customers. In the present-day situation, if organizations have to sustain diverse competition, then they have to walk a step ahead by predicting and identifying those needs and not limiting themselves to mere focus on customer satisfaction.

Having foresight and broad vision, along with a holistic perspective, enhances business and further helps to flourish. The prevailing business ecosystem poses intense challenges along with extreme comprehensive competition, ever-changing technological features, the progression of the knowledge and information economy, and the necessity for flexibility, resilience, and proficiency (Srivastava \& Bhatnagar, 2010).

\section{DOI: 10.4018/IJBIR.20210101.oa1}

\footnotetext{
This article, published as an Open Access article on December 18, 2020 in the gold Open Access journal, International Journal of Business Intelligence Research (converted to gold Open Access on January 1, 2021), is distributed under the terms of the Creative Commons Attribution License (http://creativecommons.org/licenses/by/4.0/) which permits unrestricted use, distribution, and production in any medium, provided the author of the original work and original publication source are properly credited.
} 
This approach holds for the employee markets as well. Many recruiters consider that the talent pool has not followed the existing market requirements, therefore attracting the right employees is difficult. Michael Page fromThe English recruitment agency, states that "there are clear signs that this is the long-predicted prelude to the Second War of Talent" (2015). This talent competition is apparent as the time spent by organizations on the process of recruitment is enormous. Erstwhile, there are other competing organizations poaching in for a candidate with similar skill sets and work profile. Recruitment, selection, and staffing techniques also affect the Organization and even its consequences - identifying the right fit candidate for a specific job can give an organization an economic advantage that it requires (Starineca, 2015). For highly competent employees, constricted labor markets are not a threat at all as they have enough choices available (Srivastava \&Bhatnagar, 2010). Therefore recruitments are looked upon as an essential aspect of all organizations. Thus in the persisting challenging business scenario, innovative processes related to identifying, recruiting, and developing a talented workforce have become necessary to sustain profitability. Recruitment experts predict that 2020 will witness an immense crunch in the skilled workforce (Economic Times, 2019)

As the economy worldwide is healing from the slow economic growth, it is conspicuous that there is a transformation in the talent market - establishments are appreciative of the competitive edge of having "a right fit employee." They are shifting from a "Buy" perception to a "Develop" perception to cater to their talent needs (Petkovic, 2007), precisely as far as extremely skilled and capable personnel are concerned, as the availability of high-profile jobs is higher than the number of appropriate candidates (Grobe, 2003).

In recent times, organizations have become more transparent. Everybody knows what is happening where. Aspirants are incredibly aware of how organizations function - what are their payment targets for the appropriate talent, what category of individuals get hired, and henceforth the categorization of respective applicants should be according to the differential organizations. This could be a piece of endowing information as it benefits applicants to choose the Organization they intend to apply to.

Applicants value, not only the role they play and the corresponding salary, but by and large the entire Organization. More than ever, the Organization is now an essential factor to the employees - it can make a job offer much more attractive (Bajuk, 2014). Due to this, for organizations, - branding is becoming more and more essential to accomplish a competitive advantage. The brand is considered a key-asset which makes it so important to manage it in the organizational context (Polgár, 2015).

Leading headhunters further estimate that the industry will face a shortage of skilled human resources due to digitalization and technology. Businesses have been spinning from the same yarns. There are abundant prospects for the workforce possessing technological skills despite a slowing economy. Worldwide Head Hunters highlight the necessity for developing and sustaining a digitally skilled workforce to stay ahead in the industry. Therefore besides recruitment from the open markets, campus recruitments are becoming a norm for employers. The primary purpose is to increase the pool of digitally talented workforce. The human resource professionals will face a severe challenge as this will broaden the talent gap encountered by the Indian industry.

Advances in technologies are happening at a faster pace as a result of which the nature of the business processes and the specific skills essential for the same are ever-changing. As stated by, Wong and Fieseler, 2018 - In a digitized economy, the workflow and business processes progressively transform in the digital perspective, and like wise the working population converts into digitally indigenous genre(). HR managers need to adopt technology and AI-related tools for the function of recruitment and employer branding for long term sustenance(Ryan and Wessel, 2015; Stone and Deadrick, 2015; Wrong, Giessner, van Ballen, and Roufanis, 2017). Digital expertise characterizes the individuals of the digitized human resources who regularly engage in digital pursuits for developing their skill sets (some of them are leadership skills, Colbert, Yee, and George, 2016; Yee, 2014). Having a skilled workforce is a critical aspect that places successful organizations distinctly ahead of the other ones. Attracting qualified and trained employees and further retaining them for organizational success is an important aspect. 
With the existing competition for sustenance and progress, there is heavy poaching of extraordinary talent, consequent to this is the lack of a skilled workforce. Concerned by this increasing scarcity of potential recruits, a large number of organizations have realized the significance of redesigning their reward and compensation strategies, intending to project them as the best employers, which is an effort towards employer branding. Employer branding is a long term commitment to achieve sustained economic growth and survive in dire circumstances. However, EB is incremental and involves a mind-set level change. This strategy of building upon the employer brand equity has attracted and further retained the appropriate talent pool efficiently. Talent acquisition is a vital element in employer branding. Constructing and further managing a resilient employer brand consequently proposes a potent prospect for organizations to create an economic gain (Cascio, 2019; Ceric \& Crawford, 2016). This positively influences the decisions of the prospective employees towards applying to continue with an organization along with the work inspiration (e.g., Collins \& Stevens, 2002). Therefore it is essential to identify as to what aspects are crucial for prospective employees of the generation ' $Y$ ' while choosing their employers. This perfectly compatible coupling results in fruitful wedlock and a long term symbiotic relationship. This is specifically critical as around $45 \%$ of the employers across the globe face difficulties in filling up their vacancies (Manpower Group, 2018)

In the light of these trends, the relevant questions that emerge out are:

- What are the parameters and dimensions of Employer Attractiveness(EA), especially from the perception of the prospective candidates or the employees?

- Does experience further moderate this perception?

- Do organizations need to adjust their job offers and strategies for attracting and retaining young employees?

- What are the sources that contribute towards the formation of this perception related to EB?

In our study, we intend to study the prevailing theories and outcomes from the prior literature to probe the importance of employer brand equity and its worth and value towards the recruitment process, and further pursuit to determine the elements of employer brand equity.

The paper explores the various components that qualify to be an IDEAL EMPLOYER. Ensuingly, we frame the hypotheses concerning how these dimensions may impact the individual's intentions to apply for a job. We further test the hypothesis using the relevant statistical tools on data collected from students of management and engineering disciplines; and the employees in the job market. We also check the sources of information that lead to the formation of EB perception. Lastly, we deliberate upon the outcomes and implications of our study as well as the limitations innate in our research.

\section{LITERATURE REVIEW}

The study of the literature and the subsequent reviews focused upon the understanding and the insights related to the relevance of the branding of the employer and its attractiveness for sustained development and growth of the Organization. The BRICS nations have been developing, and as a consequence, there is an augmented requirement for talent. This depicts these countries as possessing positive employment growth in the current business scenario. The persisting ability has indolence, and there are gaps in the available skill set and expertise as to the requirement of the industry. Thus this builds upon a war for talent amongst the organizations to attract the most exceptional talent towards the respective Organization (Kapur et al. 2005).

Digitalization and AI have further contributed to changing business processes across the globe. The appended graph precisely features India as a country having an extensive job market across the world. This is because the growth, development and progress that prevails here fuels an extensive job basket . Thus making this study further pertinent and relevant. 


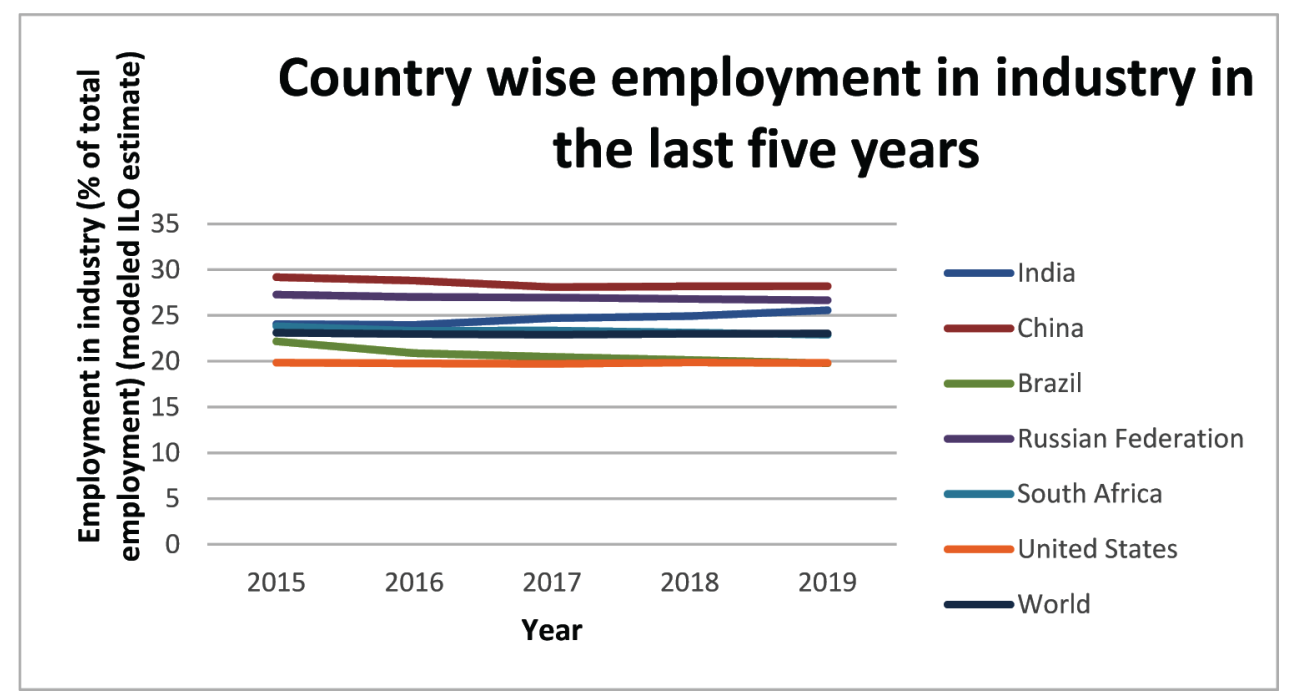

Across the globe, India is a country that possesses a prevalent youth populance, and almost more than half of the entire nation's population comprises of the working class. As per the World Economic Forum - Future of Jobs Report 2018-2019, in order to satisfy the necessities of the Fourth Industrial Revolution by 2022 a substantial amount of the prevailing workforce of India will require reskilling. To ensure and sustain growth, skill development is essential for India. Talent availability is also a crucial factor in global businesses as they assess moving operations to India to save costs and service this vast evolving market. Indian organizations are endeavoring difficulties in identifying people with the required skill set to match job requirements in the technological world of work. This gap in the required talent and expertise may inhibit India's economic growth.

It is in the 1990s that the theory of talent management emerged and has been essential as organisations have realized that their employees skills is a driving force for business success (Mandhanya \& Maitri, 2010, p.43). They further state that to track and manage their employee talent organizations strategize upon Attracting and recruiting qualified candidates with competitive backgrounds, Defining competent compensation, Training and development opportunities, performance management systems, promotion and transitioning strategies, specific retention programs

The capability of an organization to attract, maintain, and retain the appropriate employees is one of the factors which marks organizational progress and success along with giving a competitive edge over the others in the market. (Fernon, 2008). Morton (2004) defines 'Talent' as "the individuals who possess the capability to make a significant difference to the existing and future performance of the organization." Therefore, we can utilize this as a scope of considering the diagnoses for the current study. One of the components of such entities is the employees. Now how can one appeal and attract the Best and superior Talent? Moreover, further, what will appeal to the best talent in the market?

"Talent management discusses the progression of evolving and assimilating different employees, developing and retaining the existing employees, and further attracting highly skilled employees to work for the organization." (Mandhanya and Maitri, 2010, p.43). In this ever-evolving business environment, competent talent will be one of the significant resource constraints. With adult organizations aspiring to flower and flourish, newer organizations sprouting up, the budding startups, e-commerce, and others, a continually expanding demand for expertise shall prevail. In this business scenario, talent holds and will have ample alternatives and motivations and a variety to choose from, 
and the Organizations will be compelled to identify methods of elevating upon the graph that will attract talent.

Potential employees are very precise about selecting the accurate Organization as about choosing the precise and specific job (Rynes and Cable, 2003).

It is only under specific circumstances that the talent gets attracted by a particular employer and then decides to go through the process of recruitment and join the organization.

\subsection{Recruitment}

Defining recruitment is essential as it is through this process; the Talent goes through the process of selection in an organization. There are several speculations related to the importance of recruitment as one of the aspects under deliberation under the umbrella of employer attractiveness(EA). Breaugh (1992), "Employee recruitment involves those organizational activities that (1) influence the number and types of applicants who apply for a position and (2) affect whether a job offer is accepted". The definition related to recruitment, as per Barber(1998), is - Recruiting comprises persistent activities initiated by respective organizations. Nevertheless, this depiction discounts imperative inadvertent stimuli on the attraction of the applicant, including aspirant responses concerning selection processes (e.g., Gilliland, 1993) and the image of the organization(e.g., Turban and Greening, 1997). "Ways to attract and influence the job choices of top candidates." is the definition related to recruitment as ascertained by Chapman, Uggerslev, Carroll, Piasentin, and Jones (2005).

The definition of recruitment as per Breaugh (2008) is "encompassing an employer's actions that are intended to: (a) bring a job opening to the attention of the potential job candidates who do not presently work for the organization, (b) influence whether these individuals apply for the opening, (c) affect whether they retain an interest in the position until a job offer is extended, and (d) influence whether a job offer is accepted."

Recruitment can be earmarked as the main tasks related to resourcing within the ambit of HRM and is very intimately linked to the selection as mutually they are associated in identifying and selecting the best-suited candidate for the specific job or the role and the Organization on the whole. Getting the correct individuals on the right bus is the primary objective of recruitment. Armstrong (2009) explains the process of recruitment as - attracting and identifying the exact fit for the positions as well as the organization. These cite the importance of Employer Branding, which is associated with attracting prospective employees, which is closely associated with recruitment. The process of selection, elseways, is a phase within the ambit of the recruitment process that pertains to selecting the right and appropriate applicant for the specific job profile.

Predominantly the fundamental role in the resourcing of the manpower, the process of recruitment, and selection comprise tasks like identifying, attracting, and selecting the best suitable applicants (Beardwell 2004) and thus avoiding round pegs in square holes.

\subsection{Employer Branding}

The attractiveness towards the employer may happen due to variable reasons. Some may be correlated while other may be unconnected to any specifically addressed communication or information by the organization, through the perceived employer brand(EB), vide the communiqué, via the process and procedure of the recruitment, through the aspects of the role, vide the facets of the organization, and through the numerous additional features as shown by the studies undertaken by various researchers (Ambler \& Barrow, 1996; Gilly \& Wolfinbarger, 1998; Ambler, 2000; Ewing et al., 2002).

Employer branding(EB) is a suitable marketing and promotion tool and technique that supports organizations in proposing their explicit image in the psyche of the prospective applicants and placing them as an employer of preference (Saini et al., Journal of Brand Management 21, 95111). It is essential to realize the elusive borderline amongst employer brand(EB) and employer attractiveness(EA). 
Therefore in the preceding years, Employer Branding(EB) has achieved significant attention. Organizations like Deloitte(2016) and Henkel(2017) already have departments which are dedicated exclusively to reinforce their employer brand(EB). Employer Branding as defined by Ambler and Barrow (1996) is "the package of functional, economic and psychological benefits provided by employment, and identified with the employing organization." As stated by Backhaus Tikoo (2004: 502), the phrase Employer Branding (EB) indicates the distinctive features of the specific organizations as an employer of choice in association with its competitors. It accustoms the translucence of the organizations to the peripheral spectators. "Branding" as a theory, is invariably considered to differentiate an organization's products in general over that of its competitors. The concepts of branding and further employer branding have aroused as focus areas, especially concerning the process of organizational studies with specific reference to the function of Human Resource Management. In light of the contributions within these areas, it is helpful to comprehend the meaning, relevance, processes, and further importance of functioning in branded environments (Brannan, Parsons, and Priola, 2011, Land and Taylor, 2011, Brannan, Parsons, \&Priola 2015 Kornberger, 2010).

Barrow \& Moseley (2005) state that Employer Branding emphasizes the positioning of an Organization by virtue of an 'Employer Brand.'

Employer branding is related towards aspects concerned with attracting probable and retaining the existing employees. These topics comprise crafting an image of an employer, including the strategies and policies, process and procedures, furthermore the activities related to the Organization (Mandhanya and Maitri, 2010). An organization delivers its value proposition by virtue of being an employer (Mandhanya and Maitri, 2010).

Thus this is an attempt to get the right employees on board to share the organizational goals and targets. In the ambit of management sciences and organizational studies, the concept of intra regulatory effects of branding has broadened the scope of research (Karreman\& Rylander, 2008). The cultural and social process within the organizational context is studied, and brand symbolism is regarded as a process to attract customers, stakeholders, and the most valuable assets of an organization the employees. It is prominent that studies are centralized towards organizations possessing powerful consumer brands (Starbucks, Google). In the digital domain, branding is considered from a versatile perspective. Employer brand image has consistently remained influential for potential job seeker's intentions to apply to an organization (Fombrun and Shanley 1990, Rynes, 1991; Ehrhart and Ziegert, 2005s). Usually, the job-related features of roles in various organizations may be frequently analogous, predominantly in the identical business, employer branding is also generally viewed as a technique to distinguish an individual employer from the another (Lievens and Highhouse, 2003).

Franca and Pahor (2012) further argue that individual interest and organizational attributes impact decision making while applying for a job. In the process, they are providing a clear justification for the increasing emphasis on employer branding. Validation of an organization of being a preferential employer by the existing and previous personnel is a positive sign of an internal employer brand asset (Saini, 2018). Validation as a preferred employer has a strong influence on an organization's proficiency towards inviting talent along with enhancement in sales (Melian, Gonzalez, and BulchandGidumal, 2016).

\subsection{Theories of Employer Branding}

\subsubsection{Signaling Theory}

This theory explains in what way people interpret and deduce organizational features (Spence, 1973;Rynes, 1991; Turban 2001). Research indicate that people regard complete variation in the variables. Such as signals, comprising organizational features or strategies (Cable and Judge, 1994, Aiman-Smith et al., 2001; Lievens, Decaesteker, Coetsier,and Geirnaert, 2001), employers features and conduct (Rynes, 1991; Turban, Forret, and Hendrickson, 1998), and the recruitment process and procedures (Turban, Campion, and Eyring, 1995, Turban, 2001). This theory is useful for explaining that many apparent features related to the organization or a job add in value to the related attraction; 
however, studies related to this theory are not explicitly clear as to which specific characteristics are more critical compared to the others. This expanse of research will be able to predict and offer aid to the upcoming organizations for comprehending the touchpoints and concentrate more on its resources. Similarly, Organizational features attribute to perception related to an institutions strategies and the relative work environment (Robertson et al., 2005). This connect amongst organizational characteristics besides employment preference intentions are meaningful (Cable and Judge, 1996; Judge and Cable, 1997; Ryan et al., 2005). The information related to EB shared by organizations during the recruitment process significantly affects the quality traits and also the quantity of the aspirants those applying for the job (Collins \& Han, 2004; Dineen \& Noe, 2009).

Additionally, it is the responsibility of the Organizations for transmitting information and knowledge related to the prevailing culture in the organization to the candidates; likewise, the candidates play a dynamic role in collecting the required information related to the work environment(Ashford and Black, 1996; Cable and Judge, 1996). Aspirants are likely to collect info related to the culture through various medias that may be other than the organization's staffing force. For instance, the applicants or the candidates are likely to formulate their views about an organization's culture on primary know-how with the organization or basis the dialogs with companions, alumni from their institutes, professors and even previous colleagues(Fisher, Ilgen, and Hoyer, 1979).

\subsubsection{Organization Familiarity}

Prior studies indicate, that famililarity of an organization is associated with the employer attractiveness, the attraction towards an organization is more significant, familiarity augments the attractiveness (Turban \& Greening, 1997; Cable and Graham, 2000; Cable and Turban, 2001). Awareness and knowledge about a particular organization marks as a crucial predictors of an individuals intent to apply and the subsequent employer attraction (Cynthia et al., 2010). Further (Singh 2016) states that employer attractiveness(EA) is frequently professed vide increased production, profitability, and its standing in the marketplaces. As observed by Singh (2017) joint ventures with the global professions augment the Organization's branding proportion, its relative attractiveness, and this all further indorses talent attraction.

\subsubsection{The Social Identity Theory (Tajfel 1986, Ashforth and Mael 1989)}

The Organizations tend to be the crucial and vital points of reference concerning the social identity of individuals in our societal pattern. An organization that is observed positively replicates constructively on the persons employed in it (Barber, 1998). Consequently, individuals typically are appealed by such organizations. Hence reputation, familiarity of the employer, organizational awareness, and relative affirmative image (Turban et al., 1995, Cable and Turban, 2001) along with extraordinary rankings of corporate societal performance (Turban and Greening, 1996) are related positively to the attraction of the applicant. As per Lievens et. Al., 2007 - Belonging to an organization possessing a robust employer brand enriches an applicant's self-worth and reinforces his organizational identification (Lievens et al., 2007). Organizations that have favorable repute offer improved self-esteem (Brown \& Campione 1994, Cable \& Gilovich 1998).

\subsubsection{Image Theory}

The theory proposes that individuals' choices are based on organizational and job substitutes by eagle-eyes as to in what way they would acclimatize the image of their preferences (Stevens, 1998ide the method of framing, the respective individuals settle upon the applicability of the relevant data and the information towards their analysis and judgment (Stevens, 1998). This theory explains in detail the process of how individuals interpret and understand the features of the factual background and accordingly compile their conclusions (Beach, 1990). To identify their interests, the individuals adopt the systemic-heuristic processes (Dineen, Ash, and Noe 2002). 


\subsubsection{Equity Theory}

As per Adams, 1963, the Employee perceptions of the extent of contribution added to the Organization, and the relative returns on their investment, and further in what way it equates with different organizations, governs the fairness it identifies related to their engagement rapport with an organization.

\subsubsection{Critical Contact Theory}

Studies have shown that the experience and treatment during the process of recruitment, augment the employer attraction (Behling et al., 1968).

\subsubsection{Expectancy Theory}

As per Vroom(1964), People get appealed by an employment or an organization that each one identifies to be offering esteemed features like development opportunities, appreciation at the workplace, flexible work hours, empathy, reward and recognition, fair payment, and the over all balance related to working conditions (Barber and Roehling, 1993). An organization must utilize the various recruitment policies and strategies emphasizing the views of the entities that an Organization intends to appeal (Turban and Cable, 2003; Kristof et al., 2005). Some of them are flexible work hours, incentives offered(Wickham and O'Donohue, 2009).

\subsubsection{Social Learning Theory}

This theory specifies that individuals select employments or profiles based on their observed selfefficacy; that they are competent in achieving. The theory advocates that individuals will be appealed towards jobs and organizations basis the extent to which they consider they will be able to succeed in that specific Organization (Bandura (1977).

The theory of attraction-selection-attrition(Schneider, 1987): This deliberates that entities are typically enticed and appealed by organizations having common and joint attitudes, sentiments, and beliefs (this is the attraction). As stated by Chapman et al. (2005), the nature of employment or work, the organizational culture, the image of the employer, the person-organization fit, and perceptions related in respect of the recruitment and selection procedure and process have utmost association related to the job and the attractiveness of the organization. The work culture and the environment also is a component having a maximum relationship with the employment and attractiveness of the organization. Singh (2018) describes Organization necessities and needs to have a perfect team of skilled and capable employees and managers. That states in case the size or efficiency of any of the class is distorted, then it directly affects profitability and productivity.

Considering these theories, we have constructed the framework to understand EB or employer attraction by the prior researchers. The viewpoint of Berthon (2005) concerning Employer attraction or EB was more Marketing-centric. After reviewing the above theories and the following attributes, they indicate along with the basis of the expert's opinion, and the hypothesis was developed.

\subsection{The Benefits and advantages of Employer Branding}

As per Taylor (2010), the three focal benefits and advantages of employer branding(EB) are the ones correlated with recruitment, retention, and performance. The advantage of staffing certainly is the capability to appeal and attract the required talent the Organization intends to pursue. A resilient employer brand(EB) helps to promote specific job-related opportunities and express composed communications, which in turn will influence the best abilities. Likewise, to the drives related to consumer marketing, which intend towards touching upon the accurate, appropriate consumers, employer branding supports the Organization to reach a suitable talent for them. Hence, the objective may not be primarily be limited towards attracting numerous job seekers as possible, but the specific ones possessing high capacity. If an organization possesses a robust employer brand(EB), then it will be attractive and alluring as an employer, too, an extent such that they may not even need to hunt for 
Table 1.

\begin{tabular}{|c|c|c|c|c|c|c|c|}
\hline \multicolumn{8}{|c|}{$\begin{array}{l}\text { Most -preferred employer attributes(25 EmpAt items) sorted according to the mean scores of employer attractiveness items(source Eger et al. 2019) and Diwakar } \\
\text { Puri } 2018\end{array}$} \\
\hline $\begin{array}{l}\text { Australia / } \\
2005\end{array}$ & $\begin{array}{l}\text { Sri Lanka } \\
/ 2011\end{array}$ & $\begin{array}{l}\text { Norway / } \\
2013\end{array}$ & Turkey/ 2014 & Latvia / 2014 & Brazil / 2016 & CzechRep./2017 & India /2018 \\
\hline Berthon et al. & $\begin{array}{l}\text { Arachchige } \\
\& \text { Robertson }\end{array}$ & $\begin{array}{l}\text { Sivertsen } \\
\text { et al. }\end{array}$ & Alniacik et al. & Alniacik et al. & Reis \& Braga & Eger et al. & Diwakar Puri \\
\hline $\begin{array}{l}\text { Happy work } \\
\text { environment }\end{array}$ & $\begin{array}{l}\text { Gaining } \\
\text { experience } \\
\text { that will help } \\
\text { your career }\end{array}$ & $\begin{array}{l}\text { The } \\
\text { Organization } \\
\text { produces } \\
\text { high-quality } \\
\text { products and } \\
\text { services }\end{array}$ & $\begin{array}{l}\text { Recognition/appreciation } \\
\text { from management }\end{array}$ & $\begin{array}{l}\text { An above-average basic } \\
\text { salary }\end{array}$ & $\begin{array}{l}\text { Good promotion } \\
\text { opportunities } \\
\text { within the } \\
\text { Organization }\end{array}$ & $\begin{array}{l}\text { Having a good } \\
\text { relationship with } \\
\text { your colleagues }\end{array}$ & $\begin{array}{l}\text { Role and } \\
\text { empowerment } \\
\text { at the } \\
\text { Organization }\end{array}$ \\
\hline $\begin{array}{l}\text { Above- } \\
\text { average basic } \\
\text { salary }\end{array}$ & $\begin{array}{l}\text { Provides an } \\
\text { opportunity } \\
\text { for better } \\
\text { jobs in the } \\
\text { future }\end{array}$ & $\begin{array}{l}\text { Attractive } \\
\text { overall } \\
\text { compensation } \\
\text { package }\end{array}$ & $\begin{array}{l}\text { Feeling good about } \\
\text { yourself as a result } \\
\text { of working for the } \\
\text { Organization }\end{array}$ & $\begin{array}{l}\text { Good promotion } \\
\text { opportunities within the } \\
\text { Organization }\end{array}$ & $\begin{array}{l}\text { Innovative } \\
\text { employer; novel } \\
\text { work practices/ } \\
\text { forward-thinking }\end{array}$ & $\begin{array}{l}\text { Having a good } \\
\text { relationship with } \\
\text { your superiors }\end{array}$ & $\begin{array}{l}\text { An ethical } \\
\text { organization } \\
\text { with good } \\
\text { work and team } \\
\text { environment }\end{array}$ \\
\hline $\begin{array}{l}\text { Attractive } \\
\text { overall } \\
\text { compensation } \\
\text { package }\end{array}$ & $\begin{array}{l}\text { Feeling } \\
\text { good about } \\
\text { yourself as } \\
\text { a result of } \\
\text { working } \\
\text { for the } \\
\text { Organization }\end{array}$ & $\begin{array}{l}\text { An above- } \\
\text { average basic } \\
\text { salary }\end{array}$ & $\begin{array}{l}\text { Having a good } \\
\text { relationship with your } \\
\text { colleagues }\end{array}$ & $\begin{array}{l}\text { Having a good } \\
\text { relationship with your } \\
\text { colleagues }\end{array}$ & $\begin{array}{l}\text { The Organization } \\
\text { both values and } \\
\text { makes use of your } \\
\text { creativity }\end{array}$ & $\begin{array}{l}\text { Happy work } \\
\text { environment }\end{array}$ & $\begin{array}{l}\text { High Employer } \\
\text { Brand and } \\
\text { Recruiter } \\
\text { Characteristics }\end{array}$ \\
\hline $\begin{array}{l}\text { Having } \\
\text { a good } \\
\text { relationship } \\
\text { with your } \\
\text { colleagues }\end{array}$ & $\begin{array}{l}\text { Job security } \\
\text { within the } \\
\text { Organization }\end{array}$ & $\begin{array}{l}\text { Good } \\
\text { promotion } \\
\text { opportunities } \\
\text { within the } \\
\text { Organization }\end{array}$ & Happy work environment & $\begin{array}{l}\text { Feeling good about } \\
\text { yourself as a result } \\
\text { of working for the } \\
\text { Organization }\end{array}$ & $\begin{array}{l}\text { Working in } \\
\text { an exciting } \\
\text { environment }\end{array}$ & $\begin{array}{l}\text { Accepting and } \\
\text { belonging }\end{array}$ & $\begin{array}{l}\text { Familiarity } \\
\text { with the } \\
\text { Organization }\end{array}$ \\
\hline $\begin{array}{l}\text { Gaining } \\
\text { experience } \\
\text { that will help } \\
\text { your career }\end{array}$ & $\begin{array}{l}\text { Happy work } \\
\text { environment }\end{array}$ & $\begin{array}{l}\text { Opportunity } \\
\text { to apply what } \\
\text { was learned } \\
\text { at a tertiary } \\
\text { institution }\end{array}$ & $\begin{array}{l}\text { A springboard for future } \\
\text { employment }\end{array}$ & $\begin{array}{l}\text { Job security within the } \\
\text { Organization }\end{array}$ & $\begin{array}{l}\text { Having a good } \\
\text { relationship with } \\
\text { your colleagues }\end{array}$ & $\begin{array}{l}\text { Good promotion } \\
\text { opportunities } \\
\text { within the } \\
\text { Organization }\end{array}$ & $\begin{array}{l}\text { Learning and } \\
\text { Development } \\
\text { practices of the } \\
\text { Organization }\end{array}$ \\
\hline \multirow[t]{6}{*}{$\begin{array}{l}\text { Job security } \\
\text { within the } \\
\text { Organization }\end{array}$} & $\begin{array}{l}\text { Feeling } \\
\text { more self- } \\
\text { confident } \\
\text { as a result } \\
\text { of working } \\
\text { for the } \\
\text { Organization }\end{array}$ & $\begin{array}{l}\text { The } \\
\text { Organization } \\
\text { produces } \\
\text { innovative } \\
\text { products and } \\
\text { services }\end{array}$ & $\begin{array}{l}\text { Job security within the } \\
\text { Organization }\end{array}$ & $\begin{array}{l}\text { Recognition/appreciation } \\
\text { from management }\end{array}$ & $\begin{array}{l}\text { Feeling good } \\
\text { about yourself } \\
\text { as a result of } \\
\text { working for the } \\
\text { Organization }\end{array}$ & $\begin{array}{l}\text { Job security } \\
\text { within the } \\
\text { Organization }\end{array}$ & $\begin{array}{l}\text { Innovative } \\
\text { Organization } \\
\text { with products } \\
\text { and services of } \\
\text { high quality }\end{array}$ \\
\hline & & & & & & & $\begin{array}{l}\text { Organization } \\
\text { that values the } \\
\text { employee and } \\
\text { is perceived as } \\
\text { a springboard } \\
\text { for future } \\
\text { employment }\end{array}$ \\
\hline & & & & & & & $\begin{array}{l}\text { Company } \\
\text { Size and } \\
\text { International } \\
\text { presence of the } \\
\text { Organization }\end{array}$ \\
\hline & & & & & & & $\begin{array}{l}\text { Flexible work } \\
\text { options at the } \\
\text { Organization }\end{array}$ \\
\hline & & & & & & & $\begin{array}{l}\text { Attractive } \\
\text { Compensation } \\
\text { and Benefits } \\
\text { package and } \\
\text { practices of the } \\
\text { company }\end{array}$ \\
\hline & & & & & & & $\begin{array}{l}\text { Location } \\
\text { of choice } \\
\text { (especially } \\
\text { if the } \\
\text { Organization } \\
\text { can offer a } \\
\text { location near } \\
\text { the home } \\
\text { town) }\end{array}$ \\
\hline
\end{tabular}


talent. Nevertheless, the talent would be willing to select it. Indicating that branding can be further utilized in an approach that supports the Organization towards accomplishing the goal of becoming an employer of preference and prominence in the employment market (Taylor, 2010).

The procedure of recruitment usually is very expensive, and owning a strong employer brand may contribute towards cost reduction of the process. The Organization having a strong EB s has to invest less in advertisements. The applicant's pools are vast for these organizations and thus can be used when other job positions open up without any advertisement (Taylor, 2010).

The retention of employees is another area of concern for the HR professional, and a strong EB brings in the most crucial benefit of employee retention. Thus the Organization is viewed as an attractive and desirable place to work for; it creates itself as an appealing place and thus curbs the attrition rate. The function of the employer brand, concerning the retaining of employees, is to impact the relevant approach the current employees possess with respect to their employer. The feelings generated by a resilient employer brand build in self-importance and pride. (Taylor, 2010) This feeling of satisfaction touches upon the esteem necessities of a person and promotes self-assurance.

More benefits can be extracted from strong EB. One more of them is the enhanced performance of the existing employees. This results in fewer absenteeism and enhanced performance. (Taylor, 2010). Employees have a sense of pride in their employments, tend to rejoice in their work, and, thereby, have few reasons to disregard their commitments and responsibilities. The joy of the employee contributes to enhanced performance. Mostly employees who are passionate about their work are skillful and the best at whatever they are doing. An additional reason to reinforce the aspect of performance is that honor and pride may impact an approach that the employee develops a willingness to retain the job, and that results in enhanced job performance. All are well aware that the nonperformers are the first ones to exit during layoffs.

In the Indian context, the significant factor influencing application intention is media presence (Agrawal and Joseph 2010). These outcomes are different from the outcomes of the study of Collins and Stevens (2002), which are not limited to the Indian context. The investigation is to reassess the functions of the employer brand(EB). Precisely, for the prospective employees in the IT hub of Pune. The insights and the understanding related concerning the involvement of the employer brand(EB) amongst the generation $\mathrm{Y}$ assists organizations to concentrate on the relevant factors to optimize their application pool and fish out the best talent.

\section{FRAMEWORK AND HYPOTHESIS}

\subsection{Objectives}

- To identify the factors of Employer Brand Equity.

- To study factors impacting the perception of the prospective employees while selecting the employer of choice.

- To explore the sources that contribute to the formation of the knowledge of employer brand equity.

\subsection{Theoretical Underpinning and Hypothesis Development}

Employer branding and consumer branding vary, respectively; relating and encompassing a general concept to our framework is essential to offer a robust exploratory framework and structure, which the literature related to universal branding does not provide. Possessing a favorable unique employer brand(EB) remains a crucial long term asset for any organization (Carpentier et al., 2017). The relevant literature related to employer branding(EB) intends to contribute to the human resources (and or the brand) managers required and necessary diagnostic structures, empirical understanding, and the practical techniques and tools that are required to institute and further communicate employer brands(EB) effectively (Mölk and Aurer, 2018). The stint Reputation is frequently utilized to discuss 
employer brand(EB). At the same time, some authors define the reputation to be the fundamental portion of employer branding(EB) (Verčič and Ćorić, 2018).

According to Elving, Westhoff, Meeusen, and Schoonderbeek (2013), along with Saini, Rai, and Chaudhary (2014), employer brand(EB) is one of the most effective marketing instruments supporting companies that exemplify themselves well to the potential employees and applicants.

International Organization for Standardization(2016) states that - Recruitment is the discrete process of sourcing (i.e., ascertaining a group of prospective applicants). Additionally Attracting (creating and persuading awareness of the prospective intended aspirants), assessing (determining work-related awareness, skills, abilities, or any other features related to a person or a group of entities), and employing (engaging the relevant services or placing an individual to work) the talent for a prevailing or new position within an organization. Organizations have continually been concerned related to what their employees contemplate and speak about them (Dabi-rin, Kietzmann, \& Diba, 2017). Attractiveness and the prioritization of attractiveness attributes usually vary and differ basis the prevailing cultural, social and demographic features (Alniacik et al., 2014; Reis and Braga, 2016)

Even though EB and CB segment a similar primary impression - they vary considerably by aiming at diverse goals and targets, positioning strategies and policies, and also target audience (Stumpf, 2017). Significantly, the intentions of the relevant focus groups aimed at engaging by the organization/brand and their handling of the employer differ invariably. Making Decisions in an employer branding(EB) perspective takes considerable further extensive consequences. A choice to work in an explicit organization involves an intense and long-standing impact on an individual's life - much more widespread than determining whether to buy a particular product or not. The influence of branding is anticipated to be maximum amongst inexperienced customers who consequently utilize their perceptions of the brand images towards appraising and evaluating brands alongside their requirements (Aaker, 1991; Keller, 1993). Portraying analogies with the available recruitment literature, the student job seekers on-campus encounter the same situations. Most of the students lack any prior work experiences, while others have few years of experience in the corporate world. For such inexperienced employment seekers, it is challenging towards evaluation and comparing from the existing, accessible choices based on the specific attributes of the respective job and organizations. They may not know most of their characteristics. They tend to bank upon the employer brand(EB) image for support towards such decision-making. As stated by Collins and Stevens (2002), the two primary dimensions related to employer brand image (approaches, attitudes, and perceived employment attributes) are positively correlated to the application intentions and facilitate the relationship and connection amongst new recruitment practices and the application intentions and decisions.

Cable and Turban (2003) identified that job seekers' perceptions of reputation impacted job pursuits since reputation was considered as an indication related and relevant to the job aspects and attributes and impacted their expectations from organizational membership. Components of brand image are substantially associated with application intentions and actual decisions. Relevant research indicates that the impact of brand image on the relevant employee attraction is further moderated by the work experience (Agarwal and Saroop, 2009). Brand equity would be positively associated with application intention and would be moderated due to the previous work experience of the job seekers to the extent that with increasing and collective experience, job seekers tend to get converted to be more cynical and lesser influenced and impacted by the employer branding(EB) (Wilden et al., 2010)

As per Vihma (2009), the utmost significant quality of being an employer is good management. Students acknowledge excellent career growth and prospects. At times organizations may have to initiate layoffs, and if the layoffs are not approved well, then there can be issues related to employer image during the forthcoming times. (Kuulas Millward Brown 2009, cited by Vihma, 2009). The needs and necessities for Safety include basic human needs, and hence, the security, safety, and care measures offered by the employers are supreme appreciated qualities.

As per PricewaterhouseCoopers (2011), graduates are highly appreciative of the training and development opportunities. The next most significant appreciated characteristics are Flexi work hours, 
followed by financial incentives. Some graduates also stated that at times they compromised upon the appreciated intended qualities to get placed into a workplace. Though this looks fine from an employer's perspective, however, whenever the economy recovers, this set of employees are further likely to search for enhanced opportunities.

This article aims at enhancing and understanding essential characteristics that qualify an employer to be an employer of choice as per the perception of the Prospective employees-thus increasing the knowledge about the expectations of the generation Y from employers. Therefore this article attempts to shed light on the Employer branding aspect towards improving the applicant pool and designing effective strategies to attract and further retain the best talent with specific reference to the increasing digitalization. Also, it supports to address the challenges outstretched by the digitalized human resources and the workforce. Further, we try to understand the sources that contribute to the formation of this perception.

The field of EB is evolving and gaining substantial importance, prominence, and attention. Although the idea of attracting, recruiting, and further retaining employees is not new or unusual, the knowledge of the employer brand specifies a further cognizant approach of an organization as employers, according to the prospective employees and, as a result, a more deliberated tactic by organizations themselves. Globally social media recruitment has been accepted as a different and much feasible method prevailing in recent times. Therefore this study is essential considering the necessity and need for successful and prolonged EB initiatives in the context of the employment seekers.

Based on the above viewpoints, it is hypothesized:

Hypothesis: The Perception of employer brand equity is significantly different for different groups of prospective employees.

\section{RESEARCH DESIGN}

We conducted a descriptive study to evaluate the perception of potential employees concerning employer brand equity and also analyze the sources of information forming this perception. The expected sample was 150 respondents from each category. Therefore the questionnaire was administered to 200 respondents from each group. The final data set consisted of 344 (management and engineering) students who were in the last year of their program and would be very soon participating in the campus recruitments. The students were from reputed institutes in Pune, which had a well-established placement cell and assistance. The data sample included 156 employees who were already working.

After establishing a proper rapport with respondents and assuring confidentiality of the data, the tool questionnaire was administered. The study received ethical review and approval.

\subsection{Tool for Data Collection}

The questionnaire consisted of various parameters related to employer brand equity, as derived from the literature review. The Broad parameters were: Monetary benefits, Profile of interest, Opportunities abroad, Profitability, Publicity, Core values, Rewards and opportunities, Type of management, Products and services offered, Development, and growth opportunities, Social status, and Ethical behavior.

The basic questionnaire was designed based on the literature review and prior approval from two subject experts. The initial section of the survey was utilized to collect all the details of the demographics of the respondents. The balance section covered the questions in and around the EB parameters, which we arrived at, basis the literature review. To ascertain face validity (Saunders et al., 2009) of the relevant questionnaire, we formulated a pilot questionnaire that was administered to twenty respondents. To ensure a better understanding of the questions and to carry the required face and content validity, the necessary semantic changes were incorporated. The significance level 
of the EB parameters, as per the group were evaluated upon a five-point Likert Scale. The scale ranged from 'Highly Significant' (5) to 'Not Significant' (1). The latter part of the questionnaire included questions related to the information sources towards the formation of this perception. This study focuses on identifying the parameters of employer brand equity as per the perception of the Engineering students, MBA students, and the employees in the job market. These students are an essential class as they have their entire career ahead.

The study is concentrated on the evolving parameters that determine employer brand equity and the perception of the different groups of prospective and present employees, at the same time studying the sources of the information that contribute towards the formation of this perception among the different groups. The questionnaire consisted of different types of questions like multiple-choice questions, ranking, and open text questions (Evans \&Mathur, 2005).

\subsection{Sampling and Framework}

The questionnaire was administered in the student community as well as the working class to encompass comprehensive coverage. Student communities in their last year of the program at institutes, which had a well-established Placement cell and noteworthy campus placements, contributed a right amalgamation of aspirants across the various ambit of experience and industries. The questionnaires were administered during August 19, and follow-ups continued till December 19. During these specific time duration, the specific student communities (either fresh or experienced) are organizing their resumes and preparing for applying to various organizations. Thus proximate towards following their perception besides preference of the aspects that appeal to them about the potential employers.

The details of the sample size, as displayed in Table 2.

While determining the sample size that would be required to achieve the given level of accuracy, we considered the worst-case percentage (50\%).

\subsection{Data Collection Procedure}

The administration of the survey, via different modes, helped in eliminating the biases. The methods of administration were structured interviews, hard copy administration after a briefing about the study and via google forms \{internet-mediated questionnaires (Saunders et al., 2009) \} to identify the parameters of EBE and the various sources towards its formation.

The intension of the research design was to include fair representation from the required sample and the category of respondents.

The incomplete responses were eliminated, and the data was filtered and cleaned.

\subsection{Reliability and Validity}

In psychometrics, the overall consistency of a measure marks the reliability of it. A measure can be considered to be of high reliability if it yields similar outcomes during consistent circumstances. Saunders et al., 2009 state that "The internal validity and reliability of the data depends largely on the design of the questions."

Table 2.

\begin{tabular}{|l|l|}
\hline \multicolumn{2}{|c|}{ Determining Sample Size } \\
\hline Confidence Level & $95 \%$ \\
\hline Population & 200000 \\
\hline Percentage & $50 \%$ \\
\hline Confidence Interval & 8 \\
\hline Sample Size & $\mathbf{1 5 0}$ \\
\hline
\end{tabular}


An initial test was conducted for a qualitative 'check' and to ascertain if the respondents deduced and interpreted the items in the intended and expected accurate perspective. We used Cronbach's alpha test in order to identify if the questions together formed a reliable scale $(\alpha>0.70)$. Santos (1999) instituted that 0.70 is the acceptable cutoff value.

\section{DATA ANALYSIS AND RESULTS}

Data is collected from 152 Engineering students, out of which 73 were males, and 79 were females. As for the Management students, data is collected from 192 students out of these, 92 were males, and 100 were females. As for the employees, 102 were males, and 54were females tallying the total count to 156.

After reviewing the literature on application intention and Employer Brand Equity, the following essential parameters of attraction towards Employers Brand Equity are identified.

The null hypothesis that 'The perception about employer brand equity is not significantly different for different groups of students' was tested using Kruskal Wallis tests. Table 1 gives the following data.

The mean rank plot showing the average significance of parameters is as given in Figure 2.

Table 3.

\begin{tabular}{|l|l|l|l|}
\hline \multicolumn{1}{|c|}{ Economic Value } & \multicolumn{1}{c|}{ Development Value } & \multicolumn{1}{c|}{ Interest Value } & \multicolumn{1}{c|}{ Social Value } \\
\hline Application Value & Employer Brand Value & Innovative Value & Ethical and Cultural Value \\
\hline Familiarity Value & Ease Value & Location Value & \\
\hline
\end{tabular}

Table 4. Parameters of Employer Brand Equity exhibiting significance levels

\begin{tabular}{|c|c|c|c|c|c|}
\hline Parameters & $\begin{array}{l}\text { Engineering Students } \\
\qquad(N=152)\end{array}$ & $\begin{array}{c}\text { Management } \\
\text { Students }(N= \\
192)\end{array}$ & $\begin{array}{l}\text { Employees } \\
(\mathrm{N}=156)\end{array}$ & $\begin{array}{l}\text { Chi-Square } \\
\quad(d f=2)\end{array}$ & P-Value \\
\hline & \multicolumn{3}{|c|}{ Mean Ranks } & & \\
\hline Profile of your interest & 247.62 & 276.69 & 221.08 & 16.313 & 0 \\
\hline Publicity of the organization & 268.39 & 266.48 & 213.40 & 16.49 & 0 \\
\hline Rewards and opportunities & 264.54 & 264.6 & 219.47 & 12.496 & 0.002 \\
\hline Monetary benefits & 223.19 & 264.83 & 259.47 & 9.201 & 0.01 \\
\hline $\begin{array}{l}\text { Products and services offered by the } \\
\text { Organization }\end{array}$ & 274.03 & 245.18 & 234.12 & 7.182 & 0.028 \\
\hline Profitability of the organization & 271.65 & 248.37 & 232.51 & 6.48 & 0.039 \\
\hline Development and growth opportunities & 261.13 & 256.48 & 232.79 & 4.722 & 0.094 \\
\hline Type of management & 243.39 & 266.48 & 237.76 & 4.447 & 0.108 \\
\hline Ethical behavior & 251.42 & 262.64 & 234.66 & 4.056 & 0.132 \\
\hline Core values of the organization & 258.84 & 258.08 & 233.05 & 3.833 & 0.147 \\
\hline Abroad opportunities & 262.45 & 253.85 & 234.73 & 3.321 & 0.19 \\
\hline Social status of the organization & 256.31 & 257.23 & 236.55 & 2.399 & 0.301 \\
\hline
\end{tabular}


Figure 2. Mean Ranks: Parameters of EB among BE/B. Tech, MBA and Employees

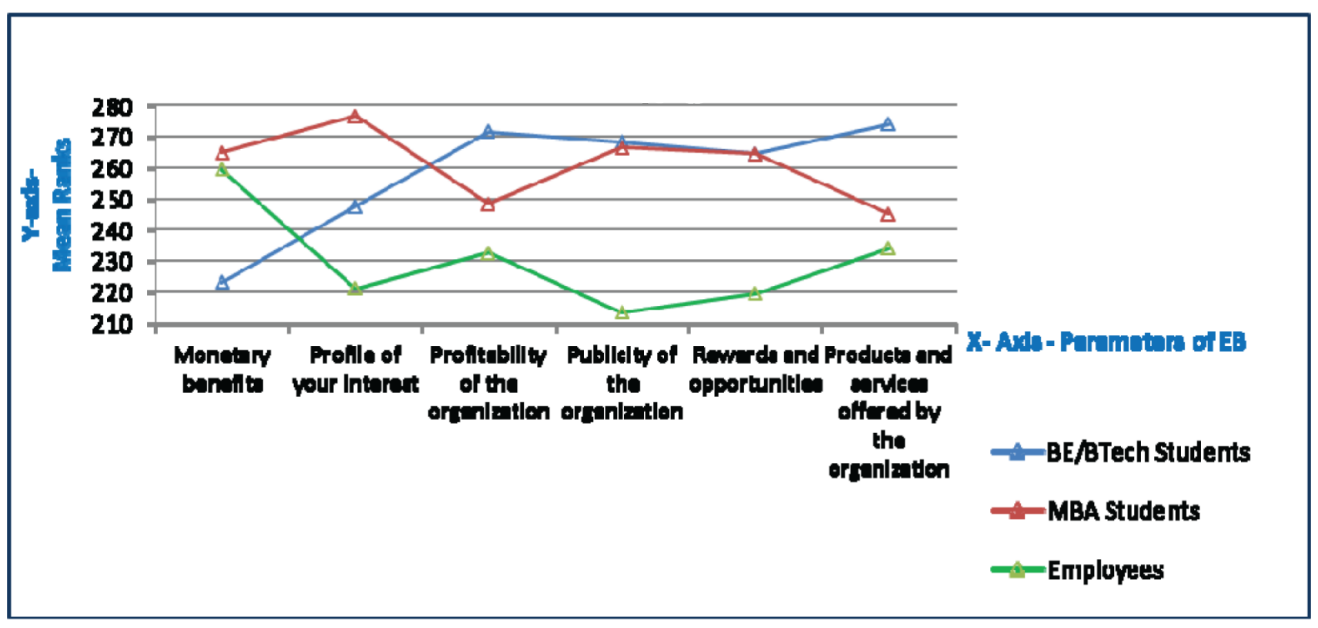

Since p-value for the parameters, Monetary benefits, Profile of interest, Profitability of the Organization, Publicity of the Organization, Rewards, and opportunities, Products, and services offered by an Organization, was observed to be less than 0.05; and hence there is strong evidence to reject the null hypothesis. The parameters defining the employer brand equity differ significantly concerning Engineering and Management Students and the workforce already in the market. Parameters like Monetary benefits, Profile of your interest, Profitability of the Organization, Publicity of the Organization, Rewards, and opportunities, Products, and services offered by the Organization differed significantly. In contrast, other parameters defining the Brand Equity do not vary with respect to Engineering and Management Students and the prospective employees.

The origins of information in the order of highest importance to the lowest importance used by Engineering and Management Students are as given in Table 6.

The above data indicate that the sources for the formation of Perception concerning Employer Brand Equity for the Management students are Social Media, Organisational events, and contacts

Table 5.

\begin{tabular}{|c|c|c|c|}
\hline Group & Rank 1 & Rank 2 & Rank 3 \\
\hline $\begin{array}{l}\text { Management } \\
(\mathrm{N}=192)\end{array}$ & $\begin{array}{l}\text { Monetary benefits, Profile of } \\
\text { your interest, Rewards, and } \\
\text { opportunities }\end{array}$ & $\begin{array}{l}\text { The profitability of the } \\
\text { Organization, Publicity of } \\
\text { the Organization, Products, } \\
\text { and services offered by the } \\
\text { Organization }\end{array}$ & Nil \\
\hline $\begin{array}{l}\text { Engineering } \\
(\mathrm{N}=152)\end{array}$ & $\begin{array}{l}\text { The profitability of the } \\
\text { Organization, Publicity of } \\
\text { the Organization, Products, } \\
\text { and services offered by the } \\
\text { Organization }\end{array}$ & $\begin{array}{l}\text { Profile of your interest, } \\
\text { Rewards, and opportunities }\end{array}$ & Monetary benefits \\
\hline $\begin{array}{l}\text { Employees } \\
(\mathrm{N}=156)\end{array}$ & & Monetary benefits & $\begin{array}{l}\text { Profile of your interest, } \\
\text { Profitability of the Organization, } \\
\text { Publicity of the Organization, } \\
\text { Rewards, and opportunities, } \\
\text { Products, and services offered by } \\
\text { the Organization, }\end{array}$ \\
\hline
\end{tabular}


Table 6.

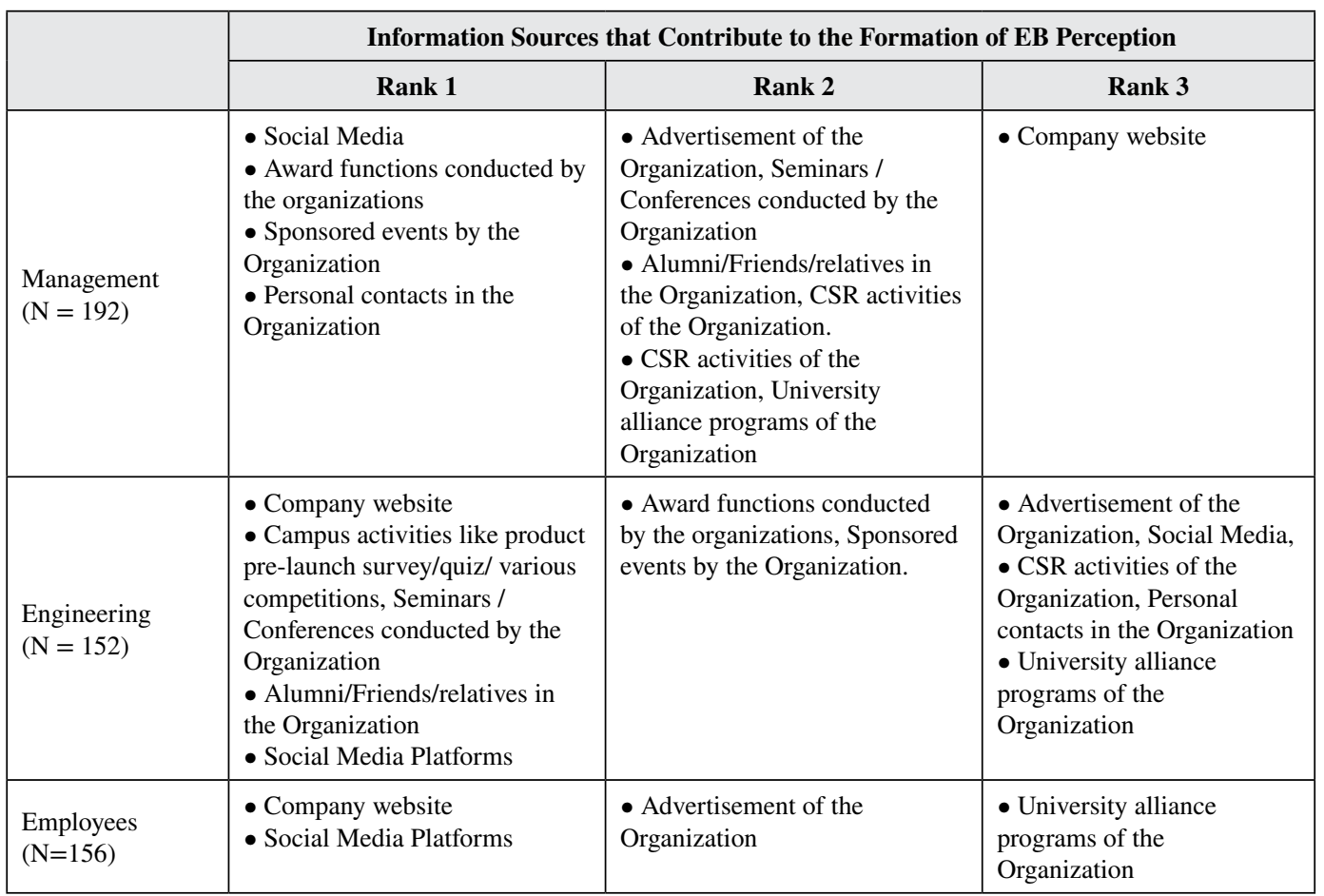

in the Organization. However, the Engineering students rely upon the information on the Company websites, organizational activities on campus, and personal contacts. As per the survey of US corporate recruiters, LinkedIn conceded that organizations possessing a robust employer brand(EB) have the benefit of $46 \%$ lower indexed costs and expenses per hire and $28 \%$ less employee attrition (Gultekin, 2011).

\section{DISCUSSIONS AND CONCLUSION}

\subsection{General}

Organizations need to have diverse employer branding models and strategies for different categories of prospective employees. Digital and social media are the most important sources of information for generation Y, and hence employer branding via these media will be more effective. Organizations must be able to connect with the prospective employees and develop relations and rapport to attract them towards them and thus enhance the applicant pool. As cited in Holbrook (2006): "What people desire are not products, but satisfying experiences." Students first learned about organizations from their activities on their college campus because they received the experience which they got from these interactions. The dimension of uniqueness encompassed the Organization to stand out differently from the ordinary and thus enhanced the brand image among the anticipated employees of the organizations and therefore impacted their perception.

\subsubsection{Engaging Through Gamification}

As per the March 2019 KPMG-Indian Federation of Sports Gaming report, the online virtual gaming business will grow substantially by $2022-23$. Young internet users possess a higher vulnerability to 
Figure 3.

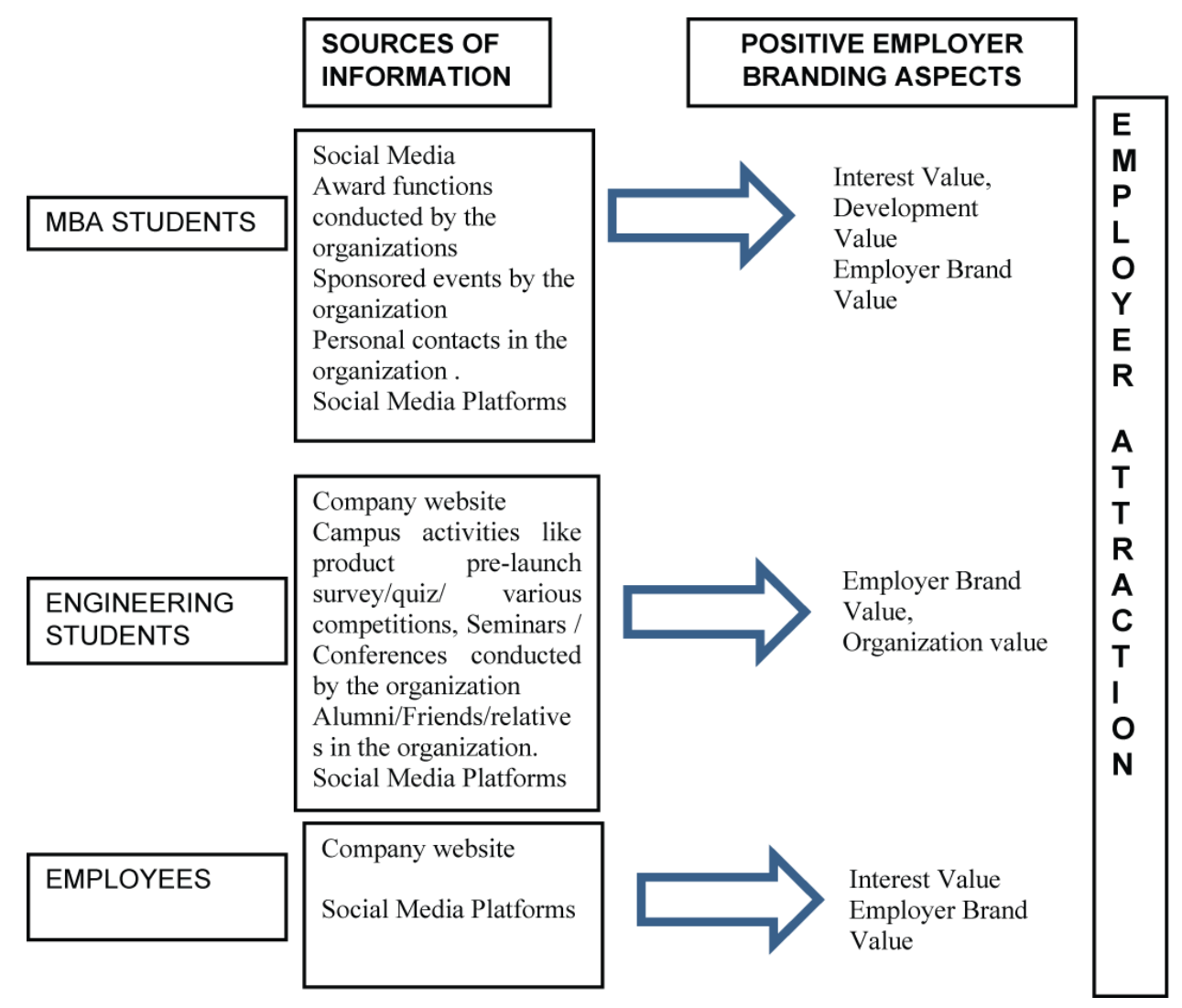

play online games. Broadly, there are around 300 million online gamers. Use of Games in a nongame context(e.g., organizations recruitment), i.e., using gaming features has been surfacing as a contemporary style(Cardador, Northcraft, and Whicker,2017; Markoulli et al., 2017) towards exploiting the individuals propensity for gaming to accomplish targets and goals rather than mere recreation and entertainment. Adopting gaming components amidst a non-game framework constructs "gameful experiences" motivating and inspiring the end-users to participate and engage through, for instance, with an organization(Deterding, Dixon, Khaled, and Nacke, 2011; Hofacker et al., 2016). Therefore, it is not astonishing that organizations are gradually trying to build "gameful experiences" towards expanding their operational environments(Cardador et al., 2017) also towards accommodating the specific interests of a progressive tech-savvy and digitized human resource. In the existing scenario, gamifying recruitment and the employer branding events influence and convert a favorable approach in HRM to further attract, appeal, motivate, and retain the best talents of the digitized workforce.

As part of Employer Branding(EB), one can consider the aspect of engaging with prospective employees using specific games. Empirical probes from diverse spheres have confirmed that thoughtful games enable players to learn (e.g., Annetta, Minogue, Holmes, and Cheng, 2009; Graafland et al., 2014); therefore, it is vital that they are competent to initiate and institute learning and express information and knowledge about the respective employers also. Thus to engage with generation $\mathrm{Y}$ examining the aspect of engaging through gamifying can be considered. For example, Shell, to engage with their prospective aspirants, used a thoughtful game towards educating them about the Organization's goals and objectives, such as coupling innovative energy resources, renewable energy, or even recycling(Ranj Serious Games GmbH, 2017; Shell, 2017). 
One of the potent tools towards constructing familiarity and awareness about EB can be the Gamification of EB. One prospect of gamifying scholastic perspectives is simplifying individuals learning entertainingly and amusingly through serious and thoughtful games that supplement an instrumental aspect of play to meager entertainment(Petelczyc, Capezio, Wang, Restubog, and Aquino, 2018). Gamifying Employer Branding(EB) activities via serious and constructive games can initiate and further influence the perception related to the organizational learning process of (potential) the employees to anhance and promote employee recruitment, motivation, and further retention in a digital environment. The integration of the area of natural education and learning - based linkage amongst employer branding(EB) besides serious and constuctive games can become a major contributing factor towards employee engagement even before they join the Organization and thus contribute towards building an affirmative EB.

From an EB perspective, designing of Serious Games should be incorporated to enhance knowledge about EB, which the individual players must be able to imbibe and apprehend; also they should be able to process and access. Eventually, serious games must invoke positive and affirmative behavioral transformations by enlightening and further educating the individuals.

Instigating a learning progression related to the employer by demonstrating a constructive game ought to deliver (prospective and the existing employees along with a positive and favorable) information base to encourage application decisions in addition to employee motivation and subsequent retention. This objective can be achieved by using building blocks like digitalization, entertainment, thinking skills, and behavioral change.

\subsection{Managerial Implications}

The significant objective of this study was to evaluate and examine the effects of brand image on the job seeker's attraction to the organization.

This is a significant study keeping in view the scarcity of skilled workforce. Talented employees within an organization are very important and essential as they shape up the basic foundation of an organization's relative knowledge base and accordingly is reflected in the substance for conception of having sustainable competitive advantage. The perceived reputation of an organization impacts its capability to recruit and retain the top class talent (Gatewood et al., 1993); also it enhances the applicant pool during recruitment. However, these factors that impact reputation assets have to be effectively communicated to the proper audience to ensure that the right kind of individuals boards the right bus to achieve organizational success. In the current study, what attracts and influences the applicant's intentions is studied. However, the perception of the respondents' about employer brand(EB) image were substantial forecasters of attraction. Consequently, Employer Branding(EB), the use of the branding principles from marketing literature to the human resource management(HRM) function, contributes towards improving brand perception to boost an organization's market position. This helps the organizations sustain and sail in turbulent situations in the competitive employment era. It necessitates and urges the employers to consider and ponder upon the impact that job applicants' perceptions has on the prevalent recruitment efforts and process. As proposed in the signaling theory, the current study specifies an indication that the potential applicants explore and use and explore data and information concerning the various aspects and dimensions of an employer's brand image in order to conclude about the employers' perceptions. This theory proposes that since, in maximum instances, applicants lack comprehensive information about an organization, they rely on the available data to conclude their understanding about an organization (Connelly et al., 2011). Accordingly, adopted knowledge and information (e.g., third party word of mouth) or customer awareness contributes to an individual's perceptions about an organization in instances where he lacks direct involvement or encounter. Though we commenced our study through the impression that parameters towards building brand image would be the same for all categories of job seekers, the results of our analyses show that the parameters of attraction differ with age, qualification, and experience. Symbolic aspects are also anticipated for all the levels of work experience; however, they became more critical with 
increasing work experience. That is, concerning the respondents having higher work experience, the symbolic attributes were intensely correlated to the Organization's attractiveness comparatively to the respondents having lesser levels of the work experience.

In contradiction to our early thinking that the respondents would be more contemptuous and less probable of being inclined by the employer brand image amidst the growing work experience, the contradiction appears to prevail. In essence, the symbolic aspects seem to anticipate significance in prospective job-seeking respondents possessing higher level of work experience. We had also hypothesized that the symbolic characteristics would be more precarious, while the respondents professed lower levels of the functional traits. Again, though the hypothesized balances were sustained, the relative effects prevailed in the reverse trend - the relationship between the symbolic attributes and the job pursuers' attraction amplified along with the growing stages of the functional aspects. The Employer brand(EB) image influences a prospective job seeker's intentions to apply to an organization (Ehrhart and Ziegert, 2005; Fombrun and Shanley, 1990). Our emphasis on the young employees exhibited that though both the symbolic and the functional aspects influenced prospective young employees, symbolic elements seemed to be further cherished and highly predictive of the employment seekers' interest. The undeviating impact of symbolic elements was much higher than that of the functional aspects, but the predictive effect enhanced with higher work experience as well as functional characteristics. Though these outcomes were not the same as we had initially anticipated, they bring out the significance of the symbolic job aspects for the young job seekers.

\subsection{Employers and Organization}

An intention earmarks the first step for applying for any job in the process of an employment decision. Any adverse sentiment or intention of the potential employment seeker forecloses the employment prospects or other ties with the specific Organization; in the process, it reduces the applicant pool for the recruiting Organization. The conclusions of the study will offer valuable inputs to recruiters to understand the thinking and expectations during the initial phase that prevails in the applicant's decision-making process. The further amalgamation of the talent management and the employer branding(EB) can make any organization to be the employer of choice. The analysis will add to the information on employer branding, recruitment, talent management, retention, and understanding of application intention of existing and prospective employees. This will contribute towards designing effective branding strategies towards attracting skilled applicants and further increasing the applicant pool. HR professionals of organizations can make their techniques better to hire new talent from the millennial generation.

\subsection{Prospective Employees}

Clear and transparent communication from the employers will provide valuable inputs to prospective employees and facilitate the decision-making process while applying for a job. Employees can make better choices by knowing the employer brand image of the Organization.

\section{LIMITATIONS}

The use of self-report cross-sectional data has its limitations, like perceptual errors. The respondents are drawn from a single geographical location, and hence restricts the generalizability of our results.

\section{CONCLUSION}

The relative effects and impact of the brand image on the job seekers' attraction towards an organization amongst a sample of young prospective employees show that both the symbolic as well as the functional aspects are positively connected with job seekers' attraction. It is clear that the parameters of brand 
equity are different for different groups of students. Therefore the organizations should design branding strategies based on the target audience to ensure the right fit. Also, it is visible that Social and digital media is a significant source of the formation of perception about the employer. Therefore clear and transparent communication using these channels with the help of Artificial Intelligence will help to develop a rapport with the prospective employees right from the initial phase of application intention and, thus, improving the application pool.

Initial recruitment was based on the gut feeling and experience of the HR managers, however, now it is more focused and related to the available data. Analytics technology is reshaping the function of recruitment. Automation is transforming the methods in which talent is resourced and retained. Artificial intelligence enables organizations to recruit talent effectively and the process is more applicant-friendly. Sourcing on social media networks has become popular. The use of Chatbots for scheduling job interviews brings inefficiency. New tools are merging to help HR personnel to identify and assess the best candidates. Additional platforms like that of Glassdoor and Linkedin provide access to valuable candidate data.

As on date, the major workforce in India comprises millennials, and these numbers will continue to grow. The future prospects of work dynamics lie upon these talented and young shoulders. They opine that in the workplace businesses need to include their perspective for consideration. The newer generation gives more importance to stepping into the workforce with the pre-conditioned skillset they also aspire to be able to acquire these skills from their respective organizations. The conventional models related to the work culture may have oppressed their capability to perform, thus making them despondent with the prevailing. An average Indian millennial has a perception and an urge to continuously learn and develop at the workplace.

They look forward to an ever incremental learning curve, scope for innovation and flexibility. Non-conformances from the Organization to feel and appease these needs of the millennial workforce may lead to attrition of jobs, thus adding in an extra expense towards recruitment. 


\section{REFERENCES}

Aaker, D. A. (1996). Building Strong Brands. Free Press.

Agrawal, R., \& Swaroop, P. (2009). Effect of Employer Brand Image on Application Intentions of B-School Undergraduates. Vision-The Journal of Business Perspective, 13(3), 42 - 49.

Agrawal, R. K., \& Swaroop, P. (2009). Effect of employer brand image on application intentions of B-School undergraduates. Vision-The Journal of Business Perspective, 13(3), 41-49. doi:10.1177/097226290901300304

Ambler, T. (2000). Marketing and the Bottom Line. London, UK: Financial Times/Prentice Hall.

Ambler, T., \& Barrow, S. (1996). The employer brand. Journal of Brand Management, 4(3), 185-206. doi:10.1057/ bm. 1996.42

Axelrod, E. L., Handfield-Jones, H., \& Welsh, T. A. (2001). War for talent: Part 2. The McKinsey Quarterly, $2,9-12$.

Backhaus, K., \& Tikoo, S. (2004). Conceptualizing and researching employer branding. Career Development International, 9(5), 501-517. doi:10.1108/13620430410550754

Balmer, J. M. T., \& Greyser, S. A. (2002). Managing the multiple identities of the corporation. California Management Review, 44(3), 72-86. doi:10.2307/41166133

Bansal, A., Phatak, Y., Gupta, I., \& Jain, R. (n.d.). Transcending Horizons Through Innovative Global 9Practices. https://books.google.co.in/books/ 13/7/2019

Barney, J. B., \& Wright, P. M. (1998). On becoming a strategic partner: The role of human resources in gaining competitive advantage. Human Resource Management, 37(1), 31-46. doi:10.1002/(SICI)1099050X(199821)37:1<31::AID-HRM4>3.0.CO;2-W

Barrow, S., \& Mosley, R. (2005). The Employer Brand. Wiley \& Sons.

Behl, A., \& Dutta, P. (2019). Social and financial aid for disaster relief operations using CSR and crowdfunding. Benchmarking, 27(2), 732-759. doi:10.1108/BIJ-08-2019-0372

Berthon, P., Ewing, M., \& Hah, L. L. (2005). Captivating company: Dimensions of attractiveness in employer branding. International Journal of Advertising, 24(2), 151-172. doi:10.1080/02650487.2005.11072912

Bhatnagar, J. (2003). A need for a paradigm shift in HR for knowledge workers. Management and Labour Studies, 28(3).

Bhatnagar, J. (2008). Talent management. In P. Budhwar \& J. Bhatnagar (Eds.), A Changing Face of HRM in India. Routledge.

Branham, L. (2005). Planning to become an employer of choice. Journal of Organizational Excellence, 24(3), 57-68. doi:10.1002/joe.20060

Cable, D., \& Turban, D. B. (2001). Establishing the dimensions, sources and value of job seekers employer knowledge during recruitment. In G. R. Ferris (Ed.), Research in Personnel and Human Resources Management (pp. 115-163). Elsevier Science. doi:10.1016/S0742-7301(01)20002-4

Cable, D. M., \& Graham, M. E. (2000). The determinants of job seekers' reputation perceptions. Journal of Organizational Behavior, 21(8), 929-947. doi:10.1002/1099-1379(200012)21:8<929::AID-JOB63>3.0.CO;2-O

Cable, D. M., \& Judge, T. A. (1996). Person-organization fit, job choice decisions and organizational entry. Organizational Behavior and Human Decision Processes, 67(3), 294-311. doi:10.1006/obhd.1996.0081

Cascio, W. F. (2010). If you must downsize, do it right. The Business School, University of Colorado Denver. http://www.employmentpolicy.org/topic/ 21/research/if-you-must-downsize-do-it-right\#

Cobb-Walgren, C. J., Ruble, C. A., \& Donthu, N. (1995). Brand equity, brand preference, and purchase intent. Journal of Advertising, 3(3), 25-40. doi:10.1080/00913367.1995.10673481 
Collins, C. J. (2007). The interactive effects of recruitment practices and product awareness on job seekers' employer knowledge and application behaviors. The Journal of Applied Psychology, 92(1), 180-190. doi:10.1037/0021-9010.92.1.180 PMID:17227159

Collins, C. J. (2007). The interactive effects of recruitment practices and product awareness on job seekers' employer knowledge and application behaviors. The Journal of Applied Psychology, 92(1), 180-190. doi:10.1037/0021-9010.92.1.180 PMID:17227159

Collins, C. J., \& Han, J. (2004). Exploring applicant pool quantity and quality: The effects of early recruitment practice strategies, corporate advertising, and firm reputation. Personnel Psychology, 57(3), 685-717. doi:10.1111/j.1744-6570.2004.00004.x

Collins, C. J., \& Han, J. (2004). Exploring applicant pool quantity and quality: The effects of early recruitment practice strategies, corporate advertising, and firm reputation. Personnel Psychology, 57, 685-717.

Collins, C. J., \& Stevens, C. K. (2002). The relationship between early recruitment-related activities and the application decisions of new labor-market entrants: A brand-equity approach to recruitment. The Journal of Applied Psychology, 87(6), 1121-1133. doi:10.1037/0021-9010.87.6.1121 PMID:12558218

Collins, C. J., \& Stevens, C. K. (2002). The relationship between early recruitment related activities and the application decisions of new labor-market entrants: A brand equity approach to recruitment. The Journal of Applied Psychology, 87(6), 1121-1133. PMID:12558218

Dawn, S., \& Biswas, S. (2010). Employer branding: A new strategic dimension of Indian corporations. Asian Journal of Management Research, 21-33.

Delgado-Ballester, E., \& Munuera-Aleman, J. L. (2005). Does brand trust matter to brand equity? Journal of Product and Brand Management, 14(3), 187-196. doi:10.1108/10610420510601058

Dewar, R., \& Werbel, J. (1979). Universalistic and contingency predictions of employee satisfaction conflict. Administrative Science Quarterly, 24(3), 426-448. doi:10.2307/2989921

Douglas, A. R., Hill, L. A., \& Conger, J. A. (2008). Winning the race for talent in emerging markets. Harvard Business Review, 86(11), 62-70. PMID:19006857

Dubey, R., Gunasekaran, A., \& Childe, S. J. (2019). Big data analytics capability in supply chain agility. Management Decision, 57(8), 2092-2112. doi:10.1108/MD-01-2018-0119

Ewing, M. T., Pitt, L. F., de Bussy, N. M., \& Berthon, P. (2002). Employment branding in the knowledge economy. International Journal of Advertising, 21(1), 3-22. doi:10.1080/02650487.2002.11104914

Fitz-enz, J. (2000). The ROI Human Capital: Measuring the Economic Value of Employee Performance. American Management Association.

Franca, V., \& Pahor, M. (2012). The strength of the employer brand: Influences and implications for recruiting. Journal of Marketing Management, 3(1), 78-122.

Gatewood, R. D., Gowan, M. A., \& Lautenschlager, G. J. (1993). Corporate image, recruitment image, and initial job choice decisions. Academy of Management Journal, 36(2), 414-427.

Gilly, M. C., \& Wolfinbarger, M. (1998). Advertising's internal audience. Journal of Marketing, 62(1), 69-88. doi:10.1177/002224299806200107

Gomes, D., \& Neves, J. (2011). Organizational attractiveness and prospective applicants' intentions to apply. Personnel Review, 40(6), 684-699. doi:10.1108/00483481111169634

Greene, W., Walls, G. D., \& Schrest, L. J. (1994). Internal marketing: The key to external marketing success. Journal of Services Marketing, 8(4), 5-13. doi:10.1108/08876049410070682

Hewitt. (2009). Point of view, what makes a company a best employer? http://www.aon.com/attachments/ thoughtleadership/pov_Best_Employer_Position_Paper.pdf

Highhouse, S., Stierwalt, S. L., Bachiochi, P., Elder, A. E., \& Fisher, G. (1999). Effects of advertised human resource management practices on attraction of African American applicants. Personnel Psychology, 52(2), 425-442. doi:10.1111/j.1744-6570.1999.tb00167.x 
Hoskisson, R. E., Eden, L., Lau, C. M., \& Wright, M. (2000). Strategy in emerging economies. Academy of Management Journal, 43(3), 249-267.

Huselid, M. A. (1993). Estimates of the impact of human resource management practices on turnover and productivity. Paper presented at the Annual Meeting of Academy of Management, Atlanta, GA.

Johnson, M. (2001). Winning the People Wars- What it Takes to Acquire and Retain the Talent You Need. Pearson Education Limited.

Joo, B. K., \& McLean, G. N. (2006). Best employer studies: A conceptual model from a literature review and a case study. Human Resource Development Review, 5(2), 228-257. doi:10.1177/1534484306287515

Joo, B.-K., \& Mclean, G. N. (2006). Best employer studies: A conceptual model from a literature review and a case study. Human Resource Development Review, 5(2), 228-257. doi:10.1177/1534484306287515

Joshi, G. Y., Sheorey, P. A., \& Gandhi, A. V. (2019). Analyzing the barriers to purchase intentions of energy efficient appliances from consumer perspective. Benchmarking, 26(5), 1565-1580. doi:10.1108/BIJ-03-2018-0082

Knox, S., \& Freeman, C. (2006). Measuring and managing employer brand image in the service industry. Journal of Marketing Management, 22(7-8), 695-716. doi:10.1362/026725706778612103

Kupper, D. M., Klein, K., \& Volckner, F. (n.d.). Human Resource Management Review. Advance online publication. doi:10.1016/j.hrmr.2019.04.002

Lemmink, J., Schuijf, A., \& Streukens, S. (2003). The role of corporate image and company employment image in explaining application intentions. Journal of Economic Psychology, 24(1), 1-15. doi:10.1016/S01674870(02)00151-4

Lievens, F., Hoye, G. V., \& Anseel, F. (2007). Organizational identity and employer image: Towards a unifying framework. British Journal of Management, 18(s1, S1), S45-S59. doi:10.1111/j.1467-8551.2007.00525.x

Lievens, F., Hoye, G. V., \& Schreurs, B. (2005). Examining the relationship between employer knowledge dimensions and organizational attractiveness: An application in a military context. Journal of Occupational and Organizational Psychology, 78(4), 53-572. doi:10.1348/09631790X26688

Love, L. F., \& Singh, P. (2011). Workplace branding: Leveraging human resources management practices for competitive advantage through 'best employer suveys'. Journal of Business and Psychology, 26(2), 175-181. doi:10.1007/s10869-011-9226-5

Michaels, E., Handfield-Jones, H., \& Axelrod, B. (2001). The War For Talent. Harvard Business School Press.

Miles, S. J., \& Mangold, G. (2004). A conceptualization of the employee branding process. Journal of Relationship Marketing, 3(2/3), 65-87. doi:10.1300/J366v03n02_05

Moroko, L., \& Uncles, M. D. (2008). Characteristics of successful employer brands. Journal of Brand Management, 16(3), 160-175. doi:10.1057/bm.2008.4

Pfeffer, J. (1994). Competitive Advantages Through People: Unleashing the Power of Workforce. Harvard Business School Press. doi:10.2307/41165742

Ployhart, R. E. (2006). Staffing in the 21st century: Challenges and strategic opportunities. Journal of Management, 32(6), 868-897. doi:10.1177/0149206306293625

Powell, G. N., \& Goulet, L. R. (1996). Recruiters' and applicants' reactions to campus interviews and employment decisions. Academy of Management Review, 39(6), 1619-1640.

Reed, P. S., \& Clark, S. M. (2004). Win-win workplace practices: Improved organizational results and improved quality of life. Report to US Department of Labor Women's Bureau. www.choose2lead.org/Publications/Study\%20 on\%20Win-Win\%20Workplace\%20Practices.pdf

Ritson, M. (2002). Marketing and HR collaborate to harness employer brand power. Marketing, 24(October), 24.

Roberson, Q. M., Collins, C. J., \& Oreg, S. (2005). The effects of recruitment message specificity on applicant attraction to organizations. Journal of Business and Psychology, 19(3), 319-339. doi:10.1007/s10869-004-2231-1

Ronn, K. (2007, June 3). Rethinking talent acquisition. Business Week Online. 
Roy, S. K. (2008). Identifying the dimensions of attractiveness of an employer brand in the Indian context. South Asian Journal of Management, 15(4), 110-130.

Rynes, S. L., Bretz, R. D. Jr, \& Gerhart, B. (1991, September). The importance of recruitment in job choice: a different way of looking. Personnel Psychology, 44(3), 487-521. doi:10.1111/j.1744-6570.1991.tb02402.x

Rynes, S.L., Bretz, R.D.J., \& Gerhart, B. (1991). The importance of recruitment in job choice: A different way of looking. Academic Press.

Saini, Rai, \& Chaudhary. (2013). What do best employer surveys reveal about employer branding and intention to apply? Academic Press.

Sartain, L., \& Schumann, M. (2006). Brand from the Inside. Wiley.

Schuler, R. S., \& Jackson, S. E. (1987). Linking competitive strategies with human resource management practices. The Academy of Management Executive, 1(3), 207-219.

SHRM Research. (2010). Employer brand in India: A strategic HR tool, society for human resource management. http://www.shrm.org/research/future workplacetrends/documents/10-0028\%20india_article_employer_brand_ v5.pdf

Singh, A. P. (2016). Do Technology Spillovers Accelerate Performance of Firms? Unravelling a Puzzle from Indian Manufacturing Industry. Annals of the University Dunarea de Jos of Galati: Fascicle: XVII. Medicine, 22(3).

Singh, A. P. (2016). R\&D spillovers \& productivity growth: Evidence from Indian manufacturing. Indian Journal of Industrial Relations, 51(4), 563-579.

Singh, A. P. (2017). Does FDI Promote Productivity? A Deep Dive. Indian Journal of Industrial Relations, 52(3).

Singh, A. P. (2017). Merge or Acquire-A Strategic Framework. Annals of the University Dunarea de Jos of Galati: Fascicle: XVII. Medicine, 3.

Singh, A. P. (2018). Does Size Matter?-The Effect of Size of Production Workers, Management Staff and Proprietors on Productivity. Theoretical Economics Letters, 8(11), 2290-2307. doi:10.4236/tel.2018.811149

Slaughter, J. E., Zickar, M. J., Highhouse, S., \& Mohr, D. C. (2004). Personality trait inferences about organizations: Development of a measure and assessment of construct validity. The Journal of Applied Psychology, 89(1), 85-103. doi:10.1037/0021-9010.89.1.85 PMID:14769122

Srivastava, P., \& Bhatnagar, J. (2008). Turnaround @ Motorola - Mobile Devices Business through the HR lever. Vikalpa.

Sullivan, J. (2004). Eight elements of a successful employment brand. http://www.ere.net/2004/02/ 23/the-8elementsof-a-successful-employmentbrand/

Taylor, M. S., \& Bergmann, T. J. (1987). Organizational recruitment activities and applicants' reactions at different stages of the recruitment process. Personnel Psychology, 40(2), 261-285. doi:10.1111/j.1744-6570.1987. tb00604.X

Taylor, M. S., \& Collins, C. J. (2000). Organizational recruitment: enhancing the intersection of theory and practice. In C. L. Cooper \& E. A. Locke (Eds.), Industrial and Organizational Psychology: Linking Theory and Practice (pp. 304-334). Basil Blackwell.

Thompson, L. F., Braddy, P. W., \& Wuensch, K. L. (2004). E-recruitment and the benefits of organizational web appeal. Paper presented at the 19th annual meeting of the Society for Industrial/ Organizational Psychology, Chicago, IL. doi:10.1037/e518632013-231

Turban, D. B. (2001). Organizational attractiveness as an employer on college campuses: An examination of the applicant population. Journal of Vocational Behavior, 58(2), 293-312. doi:10.1006/jvbe.2000.1765

Turban, D. B., \& Greening, D. (1997). Corporate social performance and organizational attractiveness to prospective employees. Academy of Management Journal, 40(3), 658-672.

Watson, N. (2002). Happy companies make happy investments stocks from our best companies to work for list trounced the S\&P 500. http:// money.cnn.com/magazines/fortune/fortune_archive/2002/05/27/323684/index.htm 
Wilcock, R. (2005) Employer branding is key in fight for talent. Personnel Today, 17(May), 4. http://www. personneltoday .com/articles/17/05/2005/29929/employer-brandingis-key-in-fight-for-talent.htm4

Wilden, R., Gudergan, S., \& Lings, I. (2010). Employer branding: Strategic implications for staff recruitment. Journal of Marketing Management, 26(1-2), 56-73. doi:10.1080/02672570903577091

Wright, P. M., \& McMahan, G. C. (1992). Alternative theoretical perspectives on strategic human resource management. Journal of Management, 18(2), 295-320. doi:10.1177/014920639201800205

Yoon. (2016). Big Companies Should Collaborate with Startups. HBR. 